\title{
Responses to metabolic challenges in dairy cows with high or low milk yield during an extended lactation
}

\author{
L. C. Marett, ${ }^{1 *}$ M. J. Auldist, ${ }^{1}$ W. J. Wales, ${ }^{1}$ K. L. Macmillan, ${ }^{2}$ F. R. Dunshea, ${ }^{3}$ and B. J. Leury ${ }^{3}$ \\ ${ }^{1}$ Agriculture Victoria, Department of Jobs, Precincts and Regions, Ellinbank, Victoria 3821, Australia \\ ${ }^{2}$ Faculty of Veterinary and Agricultural Science, The University of Melbourne, Werribee, Victoria 3030, Australia \\ ${ }^{3}$ Faculty of Veterinary and Agricultural Science, The University of Melbourne, Parkville, Victoria 3010, Australia
}

\section{ABSTRACT}

Responses of dairy cows with high or low milk yield (MY) beyond $450 \mathrm{~d}$ in milk (DIM) to 3 metabolic challenges were investigated. Twelve multiparous HolsteinFriesian cows that calved in late winter in a pasturebased system were managed for a 670-d lactation by delaying re-breeding. Cows were selected for either high MY $(18.9 \pm 1.69 \mathrm{~L} /$ cow per $\mathrm{d} ; \mathrm{n}=6)$ or low MY $(12.3 \pm 3.85 \mathrm{~L} /$ cow per $\mathrm{d} ; \mathrm{n}=6)$ at 450 DIM. Cows were housed indoors for 2 periods of $12 \mathrm{~d}$ at approximately 460 and 580 DIM. Each cow was fed freshly cut pasture (460 DIM) or pasture silage (580 DIM) plus $6.0 \mathrm{~kg}$ of DM barley grain daily (approximately 200 MJ of total metabolizable energy/cow per day). At all other times, cows were managed as a single herd and grazed pasture supplemented with cereal grain to an estimated intake of $180 \mathrm{MJ}$ of metabolizable energy/ cow per d. Cows were fitted with a jugular catheter during the final week of each experimental period. Over a period of $3 \mathrm{~d}$, each cow underwent an intravenous glucose tolerance test $(0.3 \mathrm{~g} / \mathrm{kg}$ of body weight $)$, an insulin tolerance test ( $0.12 \mathrm{IU}$ of insulin $/ \mathrm{kg}$ of body weight), and a 2-dose epinephrine challenge (0.1 and $1.6 \mu \mathrm{g} / \mathrm{kg}$ of body weight). Cows selected for high MY had greater milk and milk solids yields between 450 and 580 DIM than low MY cows (17.3 vs. $10.8 \pm 1.49$ $\mathrm{kg}$ of milk/d and $2.4 \mathrm{vs} .1 .5 \pm 0.23 \mathrm{~kg}$ of milk solids/d). The results indicated that whole body and peripheral tissue responsiveness to insulin may vary between cows of high and low MY. Following the glucose tolerance test, high MY cows had a lower plasma insulin response with a greater glucose area under the curve than low MY cows. Further, high MY cows had slower plasma glucose clearance compared with low MY cows during an insulin tolerance test. The plasma nonesterified fatty acid (NEFA) responses to the IVGTT and the

Received August 8, 2018.

Accepted December 18, 2018.

*Corresponding author: leah.marett@ecodev.vic.gov.au
ITT were similar between cows of high and low MY, but the clearance of NEFA from the plasma following both the IVGTT and ITT were slower at 580 compared with 460 DIM. The sensitivity to epinephrine was greater in high MY cows compared with low MY cows as the glucose and NEFA area under the curve and the percentage change in NEFA were greater in high MY after the low dose epinephrine challenge. However, the lipolytic but not the glucose appearance in response to epinephrine was greater in high MY cows than low MY cows. Following the high dose of epinephrine, the glucose response was lower, but the NEFA response was greater in high MY compared with low MY cows. Cows able to sustain greater MY to 580 DIM had a greater propensity for lipid mobilization, possibly enhancing nutrient partitioning to the mammary gland during the late stages of an extended lactation.

Key words: extended lactation, nutrient partitioning, insulin, epinephrine, glucose tolerance

\section{INTRODUCTION}

Managing cows for extended lactations is possible under pasture-based conditions (Kolver et al., 2007; Auldist et al., 2007; Grainger et al., 2009). However, large variation has been observed in the capacity of individual cows to sustain lactations of over $300 \mathrm{~d}$ and up to 670 d (Sorensen and Knight, 2002; Delany et al., 2010; Marett et al., 2011). Some cows are more persistent than others for many reasons. For example, primiparous cows have flatter but more persistent lactation curves than multiparous cows (Stanton et al., 1992; Tekerli et al., 2000) while increasing milking frequency from twice daily to $3 \times$ daily, or calving cows in winter or spring, can also improve persistency (Sorensen et al., 2008). Also, feeding a diet that matches the requirements for the prevailing milk yield (MY), such as a pasture-based diet with grain supplementation, rather than offering a diet in excess of energy requirements such as a TMR, can result in a greater proportion of cows reaching a target lactation length of up to 670 
d (Grainger et al., 2009; Delany et al., 2010; Marett et al., 2011). Further, differences in the endocrine and metabolic regulation of nutrient partitioning between cows has been implicated as being responsible for differences in lactation persistency. Sorensen and Knight (2002), Delany et al. (2010), and Marett et al. (2011) each reported blood plasma hormone and metabolite profiles of cows during lactations with calving intervals of 18 to 24 mo. Common features of the profiles of cows with better persistency were greater plasma concentrations of growth hormone (GH), IGF-1, and lower concentrations of glucose and leptin.

Many pathways are involved with both catabolic and anabolic regulation of metabolism, and their importance and activity change with requirements for lactation, or other physiological states, such as pregnancy (Bauman, 2000). The most important of the hormonal regulators of nutrient partitioning are those involved with the somatotropic axis, glucose metabolism and lipid metabolism. The effects of $\mathrm{GH}$ are to increase MY via a coordinated series of catabolic adaptations in various body tissues to support the use of nutrients for milk synthesis. The effects of insulin are anabolic and increase the uptake of glucose and fatty acids into peripheral tissues (nonmammary) for storage (Collier et al., 1984; McGuire et al., 1995; Bauman, 2000). Therefore, the sensitivity and responsiveness of the cow to the effect of catabolic and anabolic intermediaries play a major role in the partitioning of nutrients toward or away from lactation (Blum et al., 1983; Bauman, 2000).

Previous research into the regulation of nutrient partitioning during extended lactations indicates that many metabolic pathways exist by which Holstein-Friesian cows can sustain a lactation greater than $300 \mathrm{~d}$. A series of experiments designed to explore the regulation of nutrient partitioning during extended lactations showed that in the second $300 \mathrm{~d}$ of a $670-\mathrm{d}$ lactation, insulin sensitivity and responsiveness were increased (Marett et al., 2015, 2017), the secretion of GH in response to hypoglycaemia was reduced (Marett et al., 2014), and the lipolytic and glucogenic responses to catecholamines were also reduced (Marett et al., 2018). A recurring observation in these studies was the considerable difference between the glucose and nonesterified fatty acid (NEFA) responses to metabolic challenges at $100,250,460$, and $560 \mathrm{~d}$ of a targeted 670-d lactation. Further, each of the aforementioned experiments also examined the effect of an extra $5 \mathrm{~kg}$ of DM grain in a forage-based diet. However, the authors were unable to attribute the variation observed both within and between treatments to the extra grain offered, or the MY of the cows alone. This suggests that not only is there variation in the metabolism of cows fed nutritionally divergent diets, but there is variation between cows irrespective of diet that may explain differences in milk production and lactation persistency.

The experiments outlined in this paper investigated the regulation of nutrient partitioning in cows of high or low MY in the second $300 \mathrm{~d}$ of a 670 -d lactation. This involved measuring the responses of dairy cows to 3 metabolic challenges performed at approximately 460 and 580 DIM; namely, an intravenous glucose tolerance test (IVGTT), an insulin tolerance test (ITT), and an epinephrine challenge. We hypothesized that (1) cows with greater MY beyond 300 DIM would have lower whole body and peripheral tissue responsiveness to insulin than cows with low MY, in terms of the glucose response to an IVGTT and ITT; (2) cows with greater MY beyond 300 DIM would have lower whole body and tissue-specific responsiveness to insulin than cows with low MY in terms of the NEFA response to an IVGTT and ITT; and (3) cows with greater MY beyond 300 DIM would have greater sensitivity and responsiveness to an epinephrine challenge in terms of both the glucose and NEFA responses.

\section{MATERIALS AND METHODS}

\section{Location}

The experiment was conducted at the Department of Economic Development, Jobs, Transport and Resources Ellinbank Centre in Victoria, Australia $\left(38^{\circ} 14^{\prime} \mathrm{S}\right.$, $145^{\circ} 56^{\prime} \mathrm{E}$ ). All procedures were approved by the Department of Economic Development, Jobs, Transport and Resources Eastern Animal Ethics Committee.

\section{Cows and Management}

The cows used in this experiment were part of a larger experiment and were managed as per the control treatment outlined by Marett et al. (2011). Briefly, the experiment used 12 multiparous Holstein-Friesian cows of mixed age that calved in late July (winter). These cows were part of a single large herd that were managed for an extended lactation by delaying breeding until $\sim 450$ DIM for a target lactation length of $670 \mathrm{~d}$. The cows grazed perennial ryegrass (Lolium perenne) pasture that was supplemented with cereal grain fed twice daily in the dairy at milking times. When pasture was limiting during the summer and autumn months, pasture hay and pasture silage were also offered to achieve an estimated daily intake of $200 \mathrm{MJ}$ of ME/ cow for the first $300 \mathrm{~d}$ and $180 \mathrm{MJ}$ of ME/cow per day thereafter.

For the current experiment, the sample size was based on previous work investigating responses to metabolic 
challenges in ruminants (Denbow et al., 1986; Sechen et al., 1990). Cows were chosen for the experiment based on their MY at 300 DIM and then divided into 2 subgroups of 6 cows each according to their MY at 450 $\mathrm{DIM} \pm$ standard deviation (high MY $18.9 \pm 1.69 \mathrm{~L} /$ cow per d; or low MY $12.3 \pm 3.85 \mathrm{~L} /$ cow per d at 450 DIM). Cows were originally selected at 300 DIM based on reports that cows with greater MY in the 1 to 300 DIM period would be more persistent during the period beyond 300 DIM (Kay et al., 2009). However, in the current experiment, MY rankings changed significantly during the second spring of the lactation (between 300 and 400 DIM), so the 12 cows were allocated to either the high or low MY groups at 450 DIM, after which rankings did not change. This was consistent with reports of more persistent and less persistent cows where MY began to diverge between 300 and 400 DIM (Marett et al., 2011). Cows were housed indoors for 2 experimental periods of $12 \mathrm{~d}$ commencing when they were approximately 460 and 580 DIM (463 and $581 \pm$ 6.8 DIM). During the experimental periods each cow was fed freshly cut pasture (460 DIM) or pasture silage (580 DIM) plus $6.0 \mathrm{~kg}$ of DM barley grain daily (approximately $200 \mathrm{ME} /$ cow per d, equivalent to the high grain treatment outlined in Marett et al. (2015). Cows were fed $50 \%$ of the total daily grain intake individually in the parlor at each milking. Forage and freshly cut pasture were fed twice daily in individual feed bins while cows were restrained in stalls. Cows were released from stalls to a loafing pad after they had eaten and had access to fresh water ad libitum. They were milked twice daily at $\sim 0700$ and $1500 \mathrm{~h}$. On d 8 of each experimental period, cows were relocated to individual metabolism stalls. Cows were fitted with harnesses and chutes to collect feces and urine. The same cows were enrolled in both experimental periods.

\section{Measurements and Analyses}

Milk yield was measured for each cow at every milking during the lactation using a DeLaval Alpro milk metering system (DeLaval International, Tumba, Sweden). A composite sample of the daily milk (a.m. + p.m.) was collected using in-line milk meters (DeLaval International) every $2 \mathrm{wk}$ during the nonexperimental periods, and weekly during the experimental periods. While in metabolism stalls, cows were milked in situ into test buckets and the milk was weighed manually. Milk samples were tested for concentrations of fat, protein, and lactose using an infrared milk analyzer (model 2000, Bentley Instruments, Chaska, MN).

Each cow was weighed every 2 wk during the nonexperimental periods but weekly during the experimental periods.

\section{Metabolic Challenges}

Each cow was fitted with an indwelling jugular catheter under local anesthesia on d 8 of the experimental period and were rested for $36 \mathrm{~h}$ before the first metabolic challenge. Catheters were checked for patency every $12 \mathrm{~h}$ by taking a sample of blood and flushing with $20 \mathrm{~mL}$ of heparinized saline $(100 \mathrm{U} / \mathrm{mL})$. Each metabolic challenge was performed on each cow within the following $3 \mathrm{~d}$. Procedures for the IVGTT, ITT, and epinephrine challenge have been outlined in detail previously (Marett et al., 2014, 2015, 2017, 2018). Cows had no access to feed for $12 \mathrm{~h}$ before the commencement of each challenge. Each blood sample was collected into a 10-mL heparinized Vacutainer (BD Vacutainer Systems, Plymouth, UK), then immediately chilled on ice before being centrifuged at $1,800 \times g$ for $10 \mathrm{~min}$ at $4^{\circ} \mathrm{C}$ within $1 \mathrm{~h}$ of collection. Plasma was decanted and stored at $-20^{\circ} \mathrm{C}$.

Intravenous Glucose Tolerance Test. The IVGTT was performed on d 10 of each experimental period. Blood samples were collected at 20, 10, and 1 min before intravenous injection of $0.3 \mathrm{~g}$ of glucose $/ \mathrm{kg}$ of BW (50\% dextrose solution). Blood samples were then collected at $2,3,4,5,6,8,10,12,15,18,20,22$, $25,30,35,40,45,50,55,60,75,90,120,150,180,210$, and 240 min after glucose infusion. All plasma samples were analyzed for concentrations of insulin, glucose, and NEFA.

Insulin Tolerance Test. The ITT was performed on d 11. Blood samples were collected at 20, 10, and 1 min before the administration of an intravenous injection of $0.12 \mu \mathrm{U}$ of human insulin $/ \mathrm{kg}$ of BW (Actrapid, Novo Nordisk, Baulkham Hills, NSW, Australia). Further samples were then collected every 5 min for $120 \mathrm{~min}$ and then at 150, 180, 210, and $240 \mathrm{~min}$ after insulin infusion. Each plasma sample was analyzed for concentrations of glucose and NEFA, and samples at $-20,-10,15,30,45,60,75,90,150$, and 240 min were also analyzed for plasma GH concentration.

Epinephrine Challenge. A 2-dose epinephrine challenge was performed on d 12. Blood samples were taken at $-20,-10$, and $1 \mathrm{~min}$ before infusion of 0.1 $\mu \mathrm{g} / \mathrm{kg}$ of BW adrenaline (low dose; Adrenaline Injection BP $1 \mathrm{mg}$ in $1 \mathrm{~mL}$, AstraZeneca, NSW, Australia) through the catheter followed by $60 \mathrm{~mL}$ of heparinized saline $(50 \mathrm{U} / \mathrm{mL})$. Further samples were taken at 2, 4, $6,8,10,12,15,18,20,23,26,30,35,40,50,60,90,105$, and 120 min postinfusion of the low dose. Immediately following the 120-min sample, a $1.6 \mu \mathrm{g}$ of adrenaline $/ \mathrm{kg}$ of BW (high dose) was infused via the catheter followed by $60 \mathrm{~mL}$ of heparinized saline $(50 \mathrm{U} / \mathrm{mL})$. Samples were then taken at the same time intervals as for the low dose as well as $150 \mathrm{~min}$ postinfusion of the high 
dose. All plasma samples were analyzed for glucose and NEFA concentrations. The 2 doses of epinephrine were chosen to elucidate approximately 30 and $100 \%$ of the maximal NEFA response to epinephrine (Sechen et al., 1990), and thus provide an estimate of sensitivity and responsiveness, respectively.

\section{Plasma Analyses}

Glucose concentration $(\mathrm{m} M)$ was measured using a commercially available kit (Thermo Infinity Glucose Oxidase Liquid, Thermo Fisher, Noble Park, Victoria, Australia). Nonesterified fatty acid concentration was measured using the commercially available Wako NEFA-C kit (Wako Chemicals USA, Richmond, VA) adapted for 96-well microplates (Johnson and Peters, 1993). Insulin was measured in duplicate by a double-antibody RIA method described by Tindal et al. (1978). Insulin anti-serum was raised in a guinea pig using bovine insulin (BI 4499, Eli Lilly Pty Ltd., West Ryde, Australia). Cross-reactions were $100 \%$ with bovine insulin (lot 016666, Novo Bio Labs, Cambridge, MA). All samples were analyzed in duplicate. Intraand interassay coefficients of variation were glucose $<3$ and $<5.5 \%$; NEFA $<4$ and $<6 \%$; insulin $<5$ and $9 \%$, and $\mathrm{GH}<5.6$ and $<6.3 \%$, respectively.

\section{Calculations and Statistical Analyses}

The trapezoidal method was used to calculate the area under the response curve above baseline (AUC) for each of the metabolic challenges. Appearance rates (AR) and clearance rates (CR) were expressed as the apparent fractional rate of change for a given time period and were determined from the slope of the natural logarithm of the plasma concentration plotted against time. The changes in plasma concentrations were calculated as the difference between basal concentration and the nadir/maximum as a percentage of the basal concentration.

Data were analyzed for differences in response measures at each of the 2 stages of lactation (460 and 580 DIM) and between dietary treatments using a mixed model with restricted maximum likelihood (REML) analysis (GenStat11.0, VSN International Ltd., Hemel Hempstead, UK). The model included fixed effects for DIM and diet with the cow as the random effect. For each plasma glucose or NEFA parameter for the challenge, basal values were calculated by taking the average of the 3 samples before infusion. Recovery values were calculated as the average of the final 3 samples. Skewed data for GH concentration (basal and maximum) were analyzed after log-transformation to normalize the variance. Conclusions made from this analysis were similar to those from the analysis of the back-transformed data. The back-transformed data are presented in the table. Data were discarded for one cow from the high MY group at 580 DIM because it had been administered anti-inflammatory medication for a knee injury.

\section{RESULTS}

\section{Milk Yield and Feed Intake}

All data are presented as means \pm standard error of the difference. All cows were continued lactating until at least 580 DIM. Production data are presented in Table 1. Cows selected for high MY produced more milk and milk solids (fat + protein) than those selected for low MY (17.3 vs. $10.8 \pm 1.49 \mathrm{~kg}$ of milk/d and 2.4 vs. $1.5 \pm 0.23 \mathrm{~kg}$ of milk solids/d) and MY was greater at 460 compared with 580 DIM, overall (17.4 vs. 10.8 $\mathrm{kg}$ of milk/d). Cow BW increased between 460 to 580 DIM (630 to $690 \pm 22.8 \mathrm{~kg}, P=0.019$ ), with no difference in BW between high MY and low MY groups (646 vs. $673 \pm 35.1 \mathrm{~kg}, P=0.692)$.

\section{Metabolic Challenges}

Intravenous Glucose Tolerance Test. Basal plasma glucose concentrations were not affected by DIM but tended to be lower in high MY cows than low MY cows (3.7 vs. $4.2 \pm 0.27 \mathrm{mM}, P=0.077$; Table 2, Figure 1). Plasma glucose concentrations peaked immediately following the glucose infusion, tending to be lower at 460 DIM than at 580 DIM (14.8 vs. $16.3 \pm$ $0.79 \mathrm{~m} M, P=0.073)$ followed by a decline to baseline. The CR of glucose was greater at 460 than 580 DIM, immediately following the glucose infusion (CR 6-30; -2.3 vs. $-1.9 \pm 0.19 \% / \mathrm{min}, P=0.046)$ and later in the challenge (CR $40-90 ;-0.8$ vs. $0.00 \pm 0.07 \% / \mathrm{min}, P$ $<0.001)$. Recovery plasma glucose concentrations were not affected by stage of lactation or MY.

Basal plasma insulin concentrations tended to be lower at 460 than 580 DIM (5.0 vs. $6.3 \pm 0.77 \mu \mathrm{U} / \mathrm{mL}$, $P=0.096)$ and was lower in high MY than low MY cows (4.4 vs. $7.0 \pm 1.09 \mu \mathrm{U} / \mathrm{mL}, P=0.026)$. Plasma insulin concentrations increased following the infusion of glucose before returning to basal concentrations. Neither the rate of insulin appearance or clearance were affected by DIM or MY. However, the maximum plasma insulin concentration in response to glucose was lower at 460 than 580 DIM $(29$ vs. $38 \pm 3.4 \mu \mathrm{U} / \mathrm{mL}$, $P=0.018$ ) and was increased in low MY compared with high MY cows (42 vs. $24 \pm 4.8 \mu \mathrm{U} / \mathrm{mL}, P<$ 
Table 1. Mean daily milk yield, milk solids (fat + protein) yield, and BW for cows with either low or high milk yield (MY) at 460 or 580 DIM ${ }^{1}$

\begin{tabular}{|c|c|c|c|c|c|c|c|c|c|}
\hline Item & \multicolumn{2}{|c|}{ Low MY } & \multicolumn{2}{|c|}{ High MY } & \multicolumn{2}{|c|}{$\mathrm{SED}^{2}$} & \multicolumn{3}{|c|}{$P$-value } \\
\hline Milk yield (kg/cow) & $13.2^{\mathrm{a}}$ & $8.5^{\mathrm{b}}$ & $21.5^{\mathrm{a}}$ & $13.0^{\mathrm{b}}$ & 1.49 & 1.82 & $<0.001$ & $<0.001$ & 0.085 \\
\hline Fat $(\%)$ & 4.66 & 5.02 & 4.83 & 5.29 & 0.411 & 0.503 & 0.597 & 0.174 & 0.881 \\
\hline Fat (kg/cow) & $0.63^{\mathrm{a}}$ & $0.44^{\mathrm{b}}$ & $1.05^{\mathrm{a}}$ & $0.69^{\mathrm{b}}$ & 0.096 & 0.117 & 0.002 & $<0.001$ & 0.22 \\
\hline Lactose $(\%)$ & $4.78^{\mathrm{a}}$ & $4.58^{\mathrm{b}}$ & $5.07^{\mathrm{a}}$ & $4.79^{\mathrm{b}}$ & 0.117 & 0.143 & 0.042 & 0.009 & 0.669 \\
\hline Protein (kg/cow) & $0.51^{\mathrm{a}}$ & $0.33^{\mathrm{b}}$ & $0.81^{\mathrm{a}}$ & $0.49^{\mathrm{b}}$ & 0.065 & 0.08 & 0.002 & $<0.001$ & 0.167 \\
\hline $\mathrm{BW}(\mathrm{kg})$ & $640^{\mathrm{a}}$ & $707^{\mathrm{b}}$ & $620^{\mathrm{a}}$ & $672^{\mathrm{b}}$ & 32.8 & 46.7 & 0.692 & 0.019 & 0.737 \\
\hline
\end{tabular}

${ }^{\mathrm{a}, \mathrm{b}}$ Within a milk yield group, means with different superscripts are statistically different $(P<0.05)$.

${ }^{1}$ Values are means for 6 cows per treatment.

${ }^{2} \mathrm{SED}=$ standard error of the difference.

${ }^{3}$ Int $=$ MY $\times$ DIM interaction.

0.001). The plasma insulin $\mathrm{AUC}_{0-60}$ tended to be lower at 460 than 580 DIM $(822$ vs. $1,011 \pm 93.7 \mu \mathrm{U} \cdot \min , P$ $=0.058)$ and the plasma insulin AUC was consistently greater in the low MY compared with high MY cows $(P=0.014)$. Recovery plasma concentrations of insulin were greater in low than high MY cows (6.0 vs. $3.6 \mu \mathrm{U} /$ $\mathrm{mL}, P=0.024)$.

Basal plasma NEFA concentrations were greater at 460 compared with 580 DIM (432 vs. $154 \pm 41.9 \mu M$, $P<0.001$ ) but were not affected by MY (Table 2, Figure 1). Plasma NEFA concentrations were increased during a short latency period before decreasing to a nadir reached at approximately $40 \mathrm{~min}$ after glucose infusion. Milk yield had no effects on the plasma NEFA concentration response to the IVGTT. The minimum plasma NEFA concentrations reached were greater at 460 than 580 DIM (196 vs. $66 \pm 16.5 \mu M, P<0.001$ ). The rate of NEFA clearance from the bloodstream (CR 6-20) was faster at 460 than 580 DIM ( -3.5 vs. -2.24 $\pm 0.44 \% / \mathrm{min}, P=0.008)$. The rate of NEFA appearance in the blood was not affected by stage of lactation or MY. The plasma NEFA $\mathrm{AUC}_{0-60}$ was larger at 460 than 580 DIM $(-9,278$ vs. $-2,856 \pm 1,648 \mu M \cdot \min , P$ $<0.001)$. The recovery plasma NEFA concentrations were greater at 460 than 580 DIM (535 vs. $226 \pm 37.2$ $\mu M, P<0.001)$.

Insulin Tolerance Test. Basal plasma glucose concentration was not affected by DIM or MY (Table 3, Figure 2). Plasma glucose concentration declined following the insulin infusion. The $\%$ change, minimum concentration, and recovery concentration of plasma glucose were not affected by DIM or MY. However, the CR of glucose (CR 5-30) was not affected by DIM but was lower in high MY cows than low MY cows ( -1.7 vs. $-2.3 \pm 0.27 \% / \mathrm{min}, P=0.039)$. The appearance rate of glucose (AR 50-100) was greater at 460 DIM than
580 DIM (0.93 vs. $0.66 \pm 0.09 \% / \mathrm{min}, P=0.008)$ but was not affected by MY. The plasma glucose $\mathrm{AUC}_{0-60}$ and $\mathrm{AUC}_{0-240}$ tended to be larger at 460 than 580 DIM $(P=0.088)$.

Basal plasma NEFA concentrations were greater at 460 than 580 DIM (388 vs. $280 \pm 26.0 \mu M, P<0.001$ ) and greater in high MY than low MY cows (286 vs. $381 \pm 36.8 \mu M, P=0.018)$ with an interaction between DIM and MY (Table 3, Figure 2). The plasma NEFA concentrations decreased following the infusion of insulin before recovering to concentrations that were greater than basal. Milk yield had no effects on the plasma NEFA response to the ITT. The minimum plasma NEFA concentrations were greater at 460 than 580 DIM (193 vs. $155 \pm 17.1 \mu M, P=0.037)$. The changes in plasma NEFA (\%) and AR after the nadir (AR 50-120) were not affected by DIM. The plasma NEFA $\mathrm{AUC}_{0-20}$ and $\mathrm{AUC}_{0-60}$ were larger at 460 than 580 DIM $(P=0.048)$ but no difference was present in the $\mathrm{AUC}_{0-240}$.

Basal plasma GH concentration was not affected by DIM or MY (Table 3, Figure 2). The infusion of insulin resulted in an increase in the plasma GH concentration, which was not affected by DIM but tended to be greater in high MY cows than low MY cows (10.6 vs. $5.5 \mathrm{ng} / \mathrm{mL}, 95 \%$ CI: 5.81 to 10.93 vs. 2.89 to $11.92, P=$ 0.093). No differences were observed in the plasma $\mathrm{GH}$ AUC in response to insulin.

Epinephrine Challenge, Low Dose. Basal plasma glucose concentration was not affected by DIM (Table 4 , Figure 3). In response to the low dose of epinephrine, no difference was observed in the maximal plasma glucose response and substantial variation was observed in the fractional $\mathrm{AR}$ and $\mathrm{CR}$ of glucose, with no overall differences observed. The plasma glucose AUC was significantly greater for high MY cows for all time in- 
METABOLIC CHALLENGES IN EXTENDED LACTATION

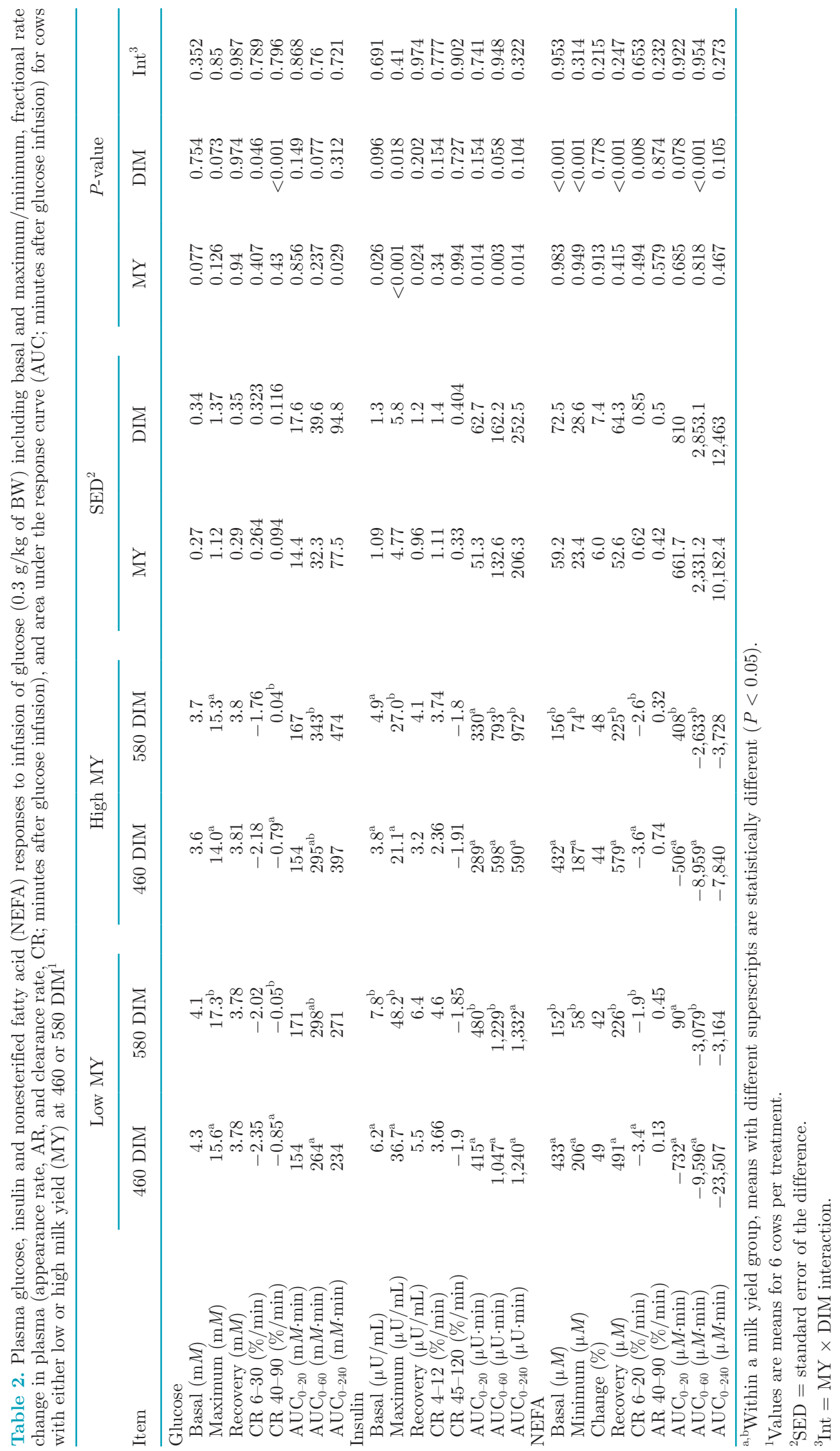



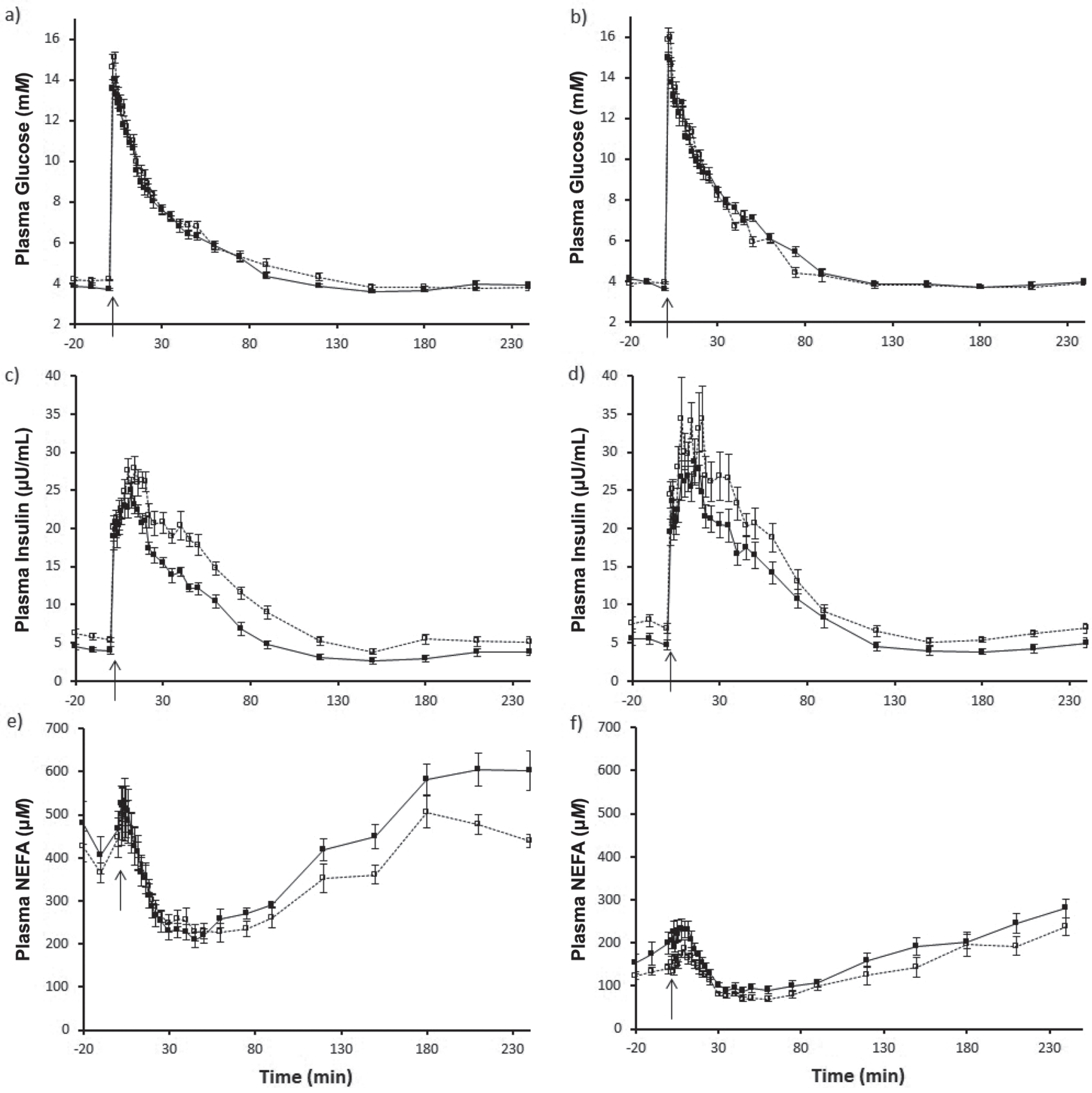

Figure 1. Responses of cows with low milk yield ( $\square$ ) and high milk yield (ם) to a glucose tolerance test. Plasma glucose response at (a) 460 and (b) 580 DIM, plasma insulin response at (c) 460 and (d) 580 DIM and plasma nonesterified fatty acid (NEFA) response at (e) 460 and (f) 580 DIM. Glucose was infused at a rate of $0.3 \mathrm{~g} / \mathrm{kg}$ of BW at time 0 min, indicated by an arrow. Error bars are SEM.

tervals calculated $(P=0.002)$ and tended to be greater at 460 compared with $580 \mathrm{DIM}$ for the glucose $\mathrm{AUC}_{0-10}$ interval (2.31 vs. $0.88 \pm 0.702 \mathrm{~m} M, P=0.056)$.

Basal plasma NEFA concentrations were greater at 460 compared with 580 DIM (399 vs. $216 \pm 34.0 \mu M, P$ $<0.001$ ), but was not affected by MY. In response to the low dose of epinephrine, the maximal plasma NEFA concentrations reached were greater at 460 compared with 580 DIM (660 vs. $328 \pm 41.1 \mu M, P<0.001$ ), and an interaction tended to be present with MY and DIM $(P=0.083)$. The change in plasma NEFA concentrations tended to be greater at 460 than 580 DIM (68 vs. 
METABOLIC CHALLENGES IN EXTENDED LACTATION

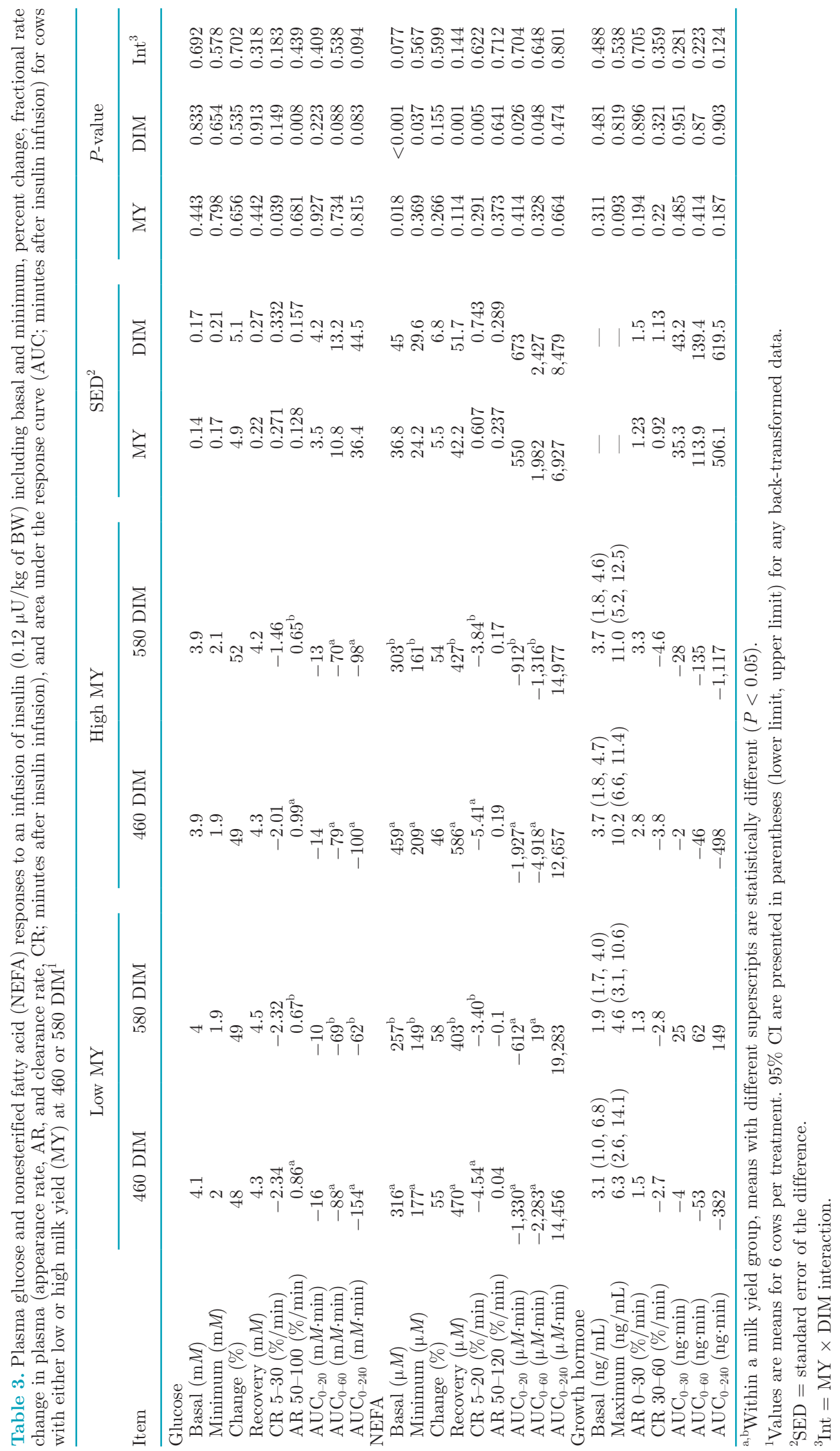


$55 \pm 6.1 \%, P=0.054$ ), and was greater in high MY cows compared with low MY cows $(74$ vs. $49 \pm 8.6 \%$, $P=0.009)$. The rate of plasma NEFA appearance was not affected by diet or stage of lactation. However, the rate of NEFA clearance from plasma was increased at
460 compared with 580 DIM $(-2.8$ vs. $-1.0 \pm 0.36, P<$ 0.001 ), but was not affected by diet. The plasma NEFA $\mathrm{AUC}_{0-10}$ and $\mathrm{AUC}_{0-30}$ were greater at 460 than $580 \mathrm{DIM}$ $\left(\mathrm{NEFA} \mathrm{AUC}_{0-10}=1,665\right.$ vs. $452 \pm 122.0 \mu M \cdot \min , P<$ 0.001 ), and were greater in high MY cows than low MY
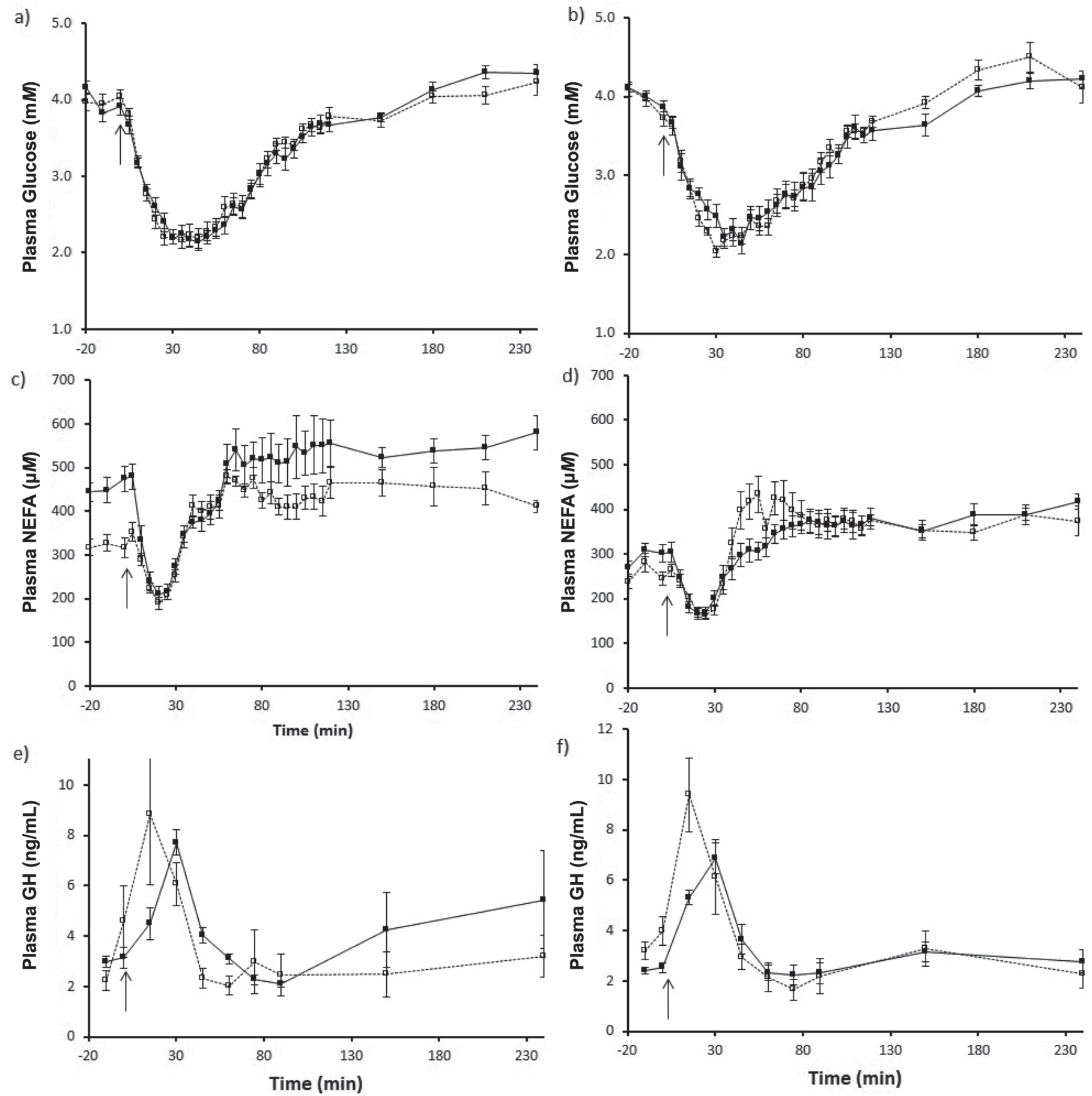

Figure 2. Responses of cows with low milk yield ( $\square$ ) and high milk yield ( $\square$ ) to an insulin tolerance test. Plasma glucose response at (a) 460 and (b) 580 DIM, plasma nonesterified fatty acid (NEFA) response at (c) 460 and (d) 580 DIM and plasma growth hormone (GH) response at (e) 460 and (f) 580 DIM. Insulin was infused at a rate of $0.12 \mu \mathrm{U} / \mathrm{kg}$ of BW at time 0 min, indicated by an arrow. Error bars are SEM. 
Table 4. Plasma glucose and nonesterified fatty acid (NEFA) responses to a low dose of epinephrine $(0.1 \mu \mathrm{g} / \mathrm{kg}$ of BW) including basal and maximum, percent change, fractional rate change in plasma (appearance rate, AR, and clearance rate, CR; minutes after insulin infusion), and area under the response curve (AUC; minutes after insulin infusion) for cows with either low or high milk yield (MY) at 460 or 580 DIM ${ }^{1}$

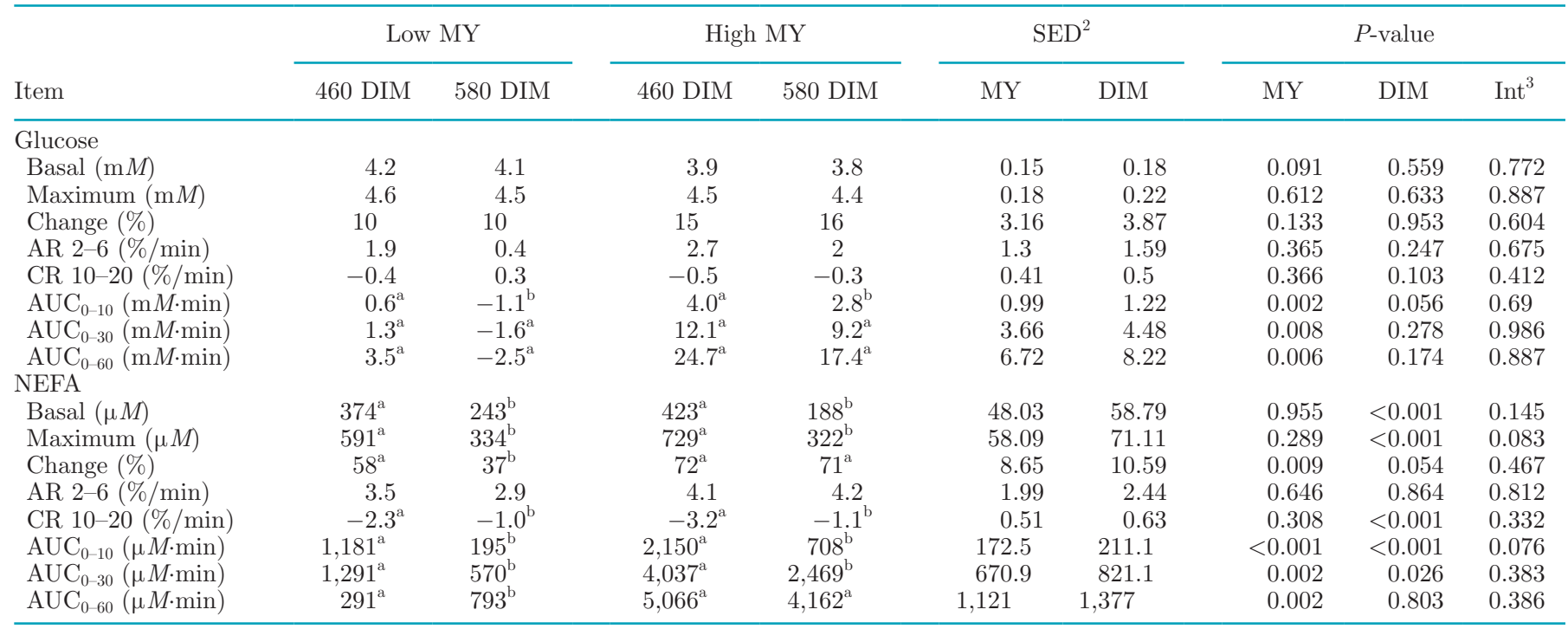

\footnotetext{
$\overline{\mathrm{a}, \mathrm{b}}$ Within a milk yield group, means with different superscripts are statistically different $(P<0.05)$.

${ }^{1}$ Values are means for 6 cows per treatment.

${ }^{2} \mathrm{SED}=$ standard error of the difference.

${ }^{3} \mathrm{Int}=\mathrm{MY} \times$ DIM interaction.
}

cows (NEFA $\mathrm{AUC}_{0-10}=1,429$ vs. $688 \pm 172.3 \mu M \cdot \mathrm{min}$, $P<0.001)$.

Epinephrine Challenge, High Dose. In response to the high dose of epinephrine, the maximal plasma glucose concentration response was greater than the low dose ( 6.6 vs. $7.3 \pm 0.28 \mu M, P=0.023)$ but was not affected by DIM. The change in plasma glucose concentration tended to be lower (64 vs. $77 \pm 6.5 \%, P=$ 0.067) in high MY cows compared with low MY cows. The plasma appearance and clearance rates of glucose, and the AUC were not significantly affected by DIM or MY. No interactions were observed between DIM and MY for the plasma glucose concentration response to the high dose of epinephrine.

In response to the high dose of epinephrine, the maximal plasma NEFA response concentrations were increased at 460 versus 580 DIM (883 vs. $477 \pm 64.0$ $\mu M, P<0.001)$ and tended to be greater in cows with high MY than low MY (766 vs. $595 \pm 90.5 \mu M, P=$ 0.073; Table 5, Figure 4). Further, the change in plasma NEFA concentrations was greater in cows with high MY compared with low MY (127 vs. $88 \pm 18.4 \%, P$ $=0.046)$. The plasma AR of NEFA was not affected by DIM or MY. However, the fractional rate of NEFA clearance from plasma was greater at 460 than 580 DIM $(-3.5$ vs. $-2.1 \pm 0.32, P<0.001)$, and was faster in cows with high MY than cows with low MY ( -3.5 vs. $-2.1 \pm 0.45 \mu M \cdot \min , P=0.006)$. Further, the plasma NEFA AUC for all time intervals was greater at 460
DIM than 580 DIM $(P=0.019)$, and in cows with high MY than low MY for $\mathrm{AUC}_{0-10}$ and $\mathrm{AUC}_{0-30}(P=$ 0.023). No interactions were observed between MY and DIM for the plasma NEFA concentration response to the high dose of epinephrine.

\section{DISCUSSION}

The results presented here expand on a series of reports by Marett et al. (2011, 2014, 2015, 2017, 2018) that investigated the regulation of nutrient partitioning in Holstein-Friesian cows during an extended lactation. It is well documented that as lactation progresses, cows partition an increased proportion of dietary energy to body tissue stores at the expense of milk production during traditional lactations (Bauman, 2000), and to a lesser extent during extended lactations (Sorensen and Knight, 2002; Grainger et al., 2009; Marett et al., 2011). Few reports are available on the metabolic and endocrine regulation of nutrient partitioning beyond 300 DIM. Those that are published (Marett et al., $2014,2015,2017,2018$ ) have been unable to attribute variation in metabolite and hormone concentrations beyond 300 DIM to either diet or MY alone. Cow BW showed a concurrent increase with increasing DIM, but no difference was observed due to MY in the current experiment, although cows of high MY had numerically lower BW than low MY cows, which is consistent with previous reports of nutrient partitioning during 

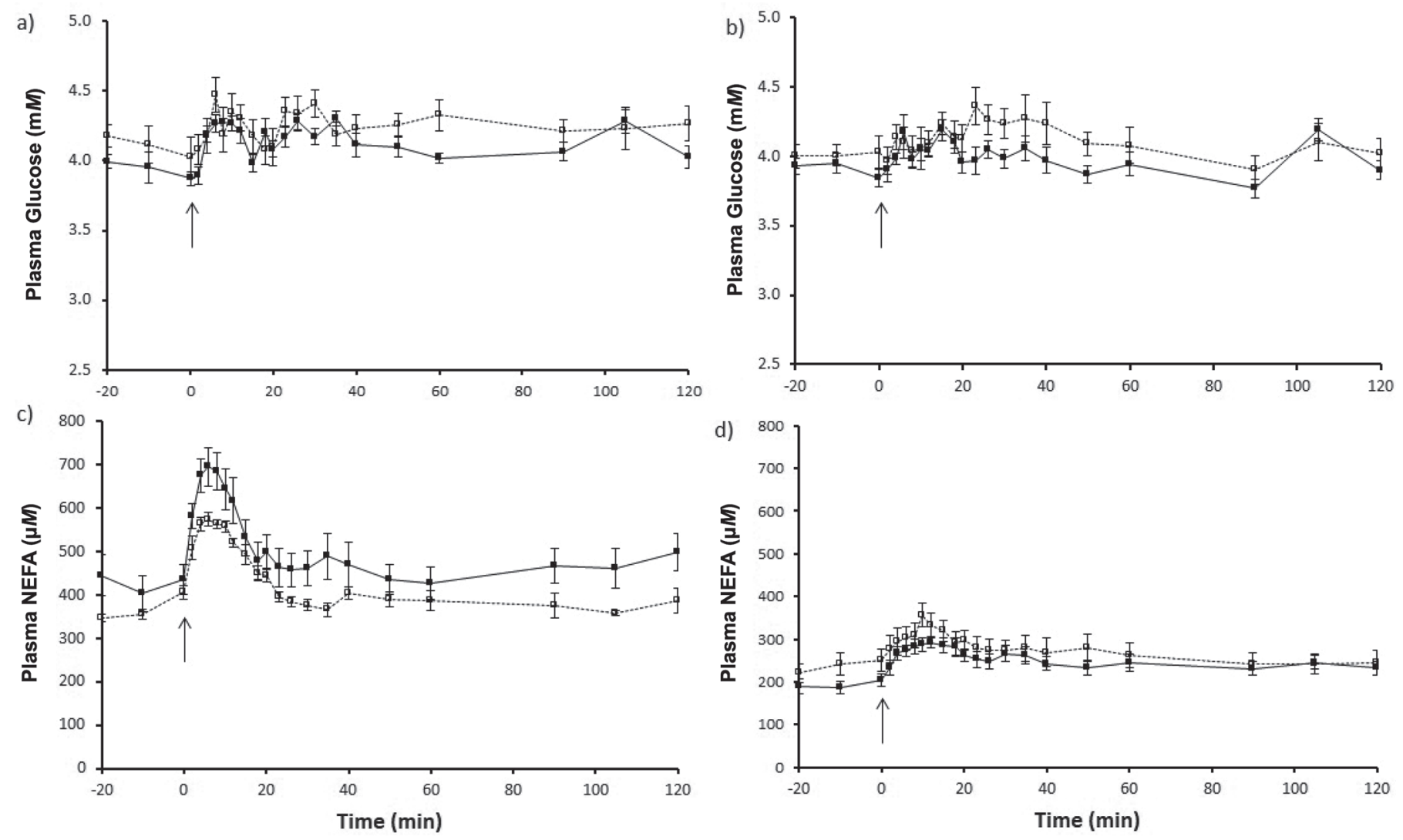

Figure 3. Responses of cows with low milk yield ( $\square$ ) and high milk yield (ם) to a low-dose epinephrine challenge. Plasma glucose response at (a) 460 and (b) 580 DIM and plasma nonesterified fatty acid (NEFA) response at (c) 460 and (d) 580 DIM. Epinephrine was infused at a dose of $0.1 \mu \mathrm{g} / \mathrm{kg}$ of BW at time $0 \mathrm{~min}$, indicated by arrows. Error bars are SEM.

extended lactations (Grainger et al., 2009; Marett et al., 2011).

Whole body insulin responsiveness, in terms of the glucose response to the IVGTT, was similar in cows with high MY compared to cows with low MY. This is inconsistent with our first hypothesis that high MY cows would have a lower responsiveness to insulin in terms of the glucose response to the IVGTT. High MY cows had a lower maximum insulin concentration and insulin AUC, but a greater glucose AUC overall than low MY cows. Thus, the high MY cows required less insulin to elicit the same glucose response as low MY cows. This may be due to inherently lower pancreatic responsiveness to hyperglycemia in high MY cows or variation in the sensitivity and responsiveness to counter-regulatory responses to glucose infusion (i.e., glucagon, epinephrine, cortisol, or GH secretion; Brehm et al., 2006). Both of these responses would favor maintaining substrate supply to the mammary gland for milk synthesis in high MY cows. The current results indicate that beyond 450 DIM, there is minimal variation in the whole body responsiveness to endogenous insulin in cows with varied MY or persistency.
The ITT investigates the insulin responsiveness of insulin-dependent tissues, primarily adipose and skeletal muscle tissues (Kaneko, 1997). Peripheral tissue responsiveness to insulin, in terms of glucose metabolism response to the ITT, was similar between high and low yielding cows. Although few differences were discernible between high and low MY cows, the glucose CR was lower in high MY cows than low MY cows. This is indicative of a lower degree of tissue-specific uptake of glucose in response to exogenous insulin and supports the second part of our first hypothesis. These results are in agreement with data from Buckley et al. (1982) which showed that goats with increased MY had slower rates of glucose clearance than low yielding goats. It is also consistent with reports that high yielding dairy cows undergoing traditional 300-d lactations had a greater degree of insulin resistance than lower yielding counterparts, regardless of whether the increased MY was due to treatment with recombinant somatotropin (Sechen et al., 1990) or simply genetic merit (Cronje, 2000; Chagas et al., 2009). Cows with greater MY beyond 450 DIM may have lower responsiveness to insulin than lower yielding cows. Further research is warranted 
to confirm this, but it would be consistent with an increased homeorhetic priority of milk production in more persistent cows.

The high MY cows had a lower responsiveness to the anti-lipolytic effects of endogenous insulin compared with the low MY cows. Adipose tissue responsiveness to insulin was lower in high MY cows than low MY cows. This supports our second hypothesis. Nonesterified fatty acid removal from plasma is dependent on tissue uptake and the rate of oxidation or re-esterification of fatty acids, processes that are regulated to a large extent by insulin (Ferrannini et al., 1997). Following the IVGTT, the high MY cows had a greater maximal insulin response to the glucose load than low MY cows, with no difference in NEFA clearance rate or nadir. Thus, following the ITT, the percent change in NEFA was numerically lower in high MY cows, which is also consistent with decreased responsiveness to insulin. Sechen et al. (1989) reported decreased responsiveness to the anti-lipolytic actions of insulin in cows treated with bST. Cows with decreased responsiveness to insulin had increased MY in response to bST treatment, accompanied by elevated plasma NEFA concentrations. The authors suggested that tissue responsiveness to insulin may be strongly associated with MY and basal NEFA concentrations, in addition to plasma concentrations of GH. The current data are consistent with this. Further, cows that have increased persistency, and increased MY >300 DIM, had elevated plasma concentrations of $\mathrm{GH}$, which would promote lipolysis, and potentially decrease tissue response to insulin (Bauman, 2000). It is not possible to establish true rates of lipolysis and lipogenesis without the parallel measurement of glycerol (Dunshea et al., 1990). However, it is possible that the rate of intracellular re-esterification of fatty acids in these cows was high given the low basal plasma NEFA concentration measured at 460 and 580 DIM and a concomitant increase in BW as lactation progressed. Cows with greater MY during the extended phase of the lactation had a lower responsiveness to insulin than lower yielding cows as a mechanism to promote substrate availability for milk production.

The sensitivity of cows to epinephrine was greater in cows with high MY than those with low MY. This is consistent with the first part of our third hypothesis. The glucose AUC, percent change in NEFA, and the NEFA AUC were greater in high MY cows compared with low MY cows. This indicates that the glucogenic and lipolytic sensitivity to a catecholamine is greater in cows of greater MY potential beyond 300 DIM. The greatest sensitivity to catecholamines occurs at the time of the greatest requirement for lipid mobilization, which is typically early lactation (Dunshea et al., 1990; Tilton et al., 1999). Our current data are in agreement with this. Although Marett et al. (2018) found a greater responsiveness to epinephrine in cows fed $6 \mathrm{~kg}$ of grain

Table 5. Plasma glucose and nonesterified fatty acid (NEFA) responses to a high dose of epinephrine (1.6 $\mu \mathrm{g} / \mathrm{kg}$ of BW) including basal and maximum, percent change, fractional rate change in plasma (appearance rate, AR, and clearance rate, CR; minutes after insulin infusion), and area under the response curve (AUC; minutes after insulin infusion) for cows with either low or high milk yield (MY) at 460 or 580 DIM ${ }^{1}$

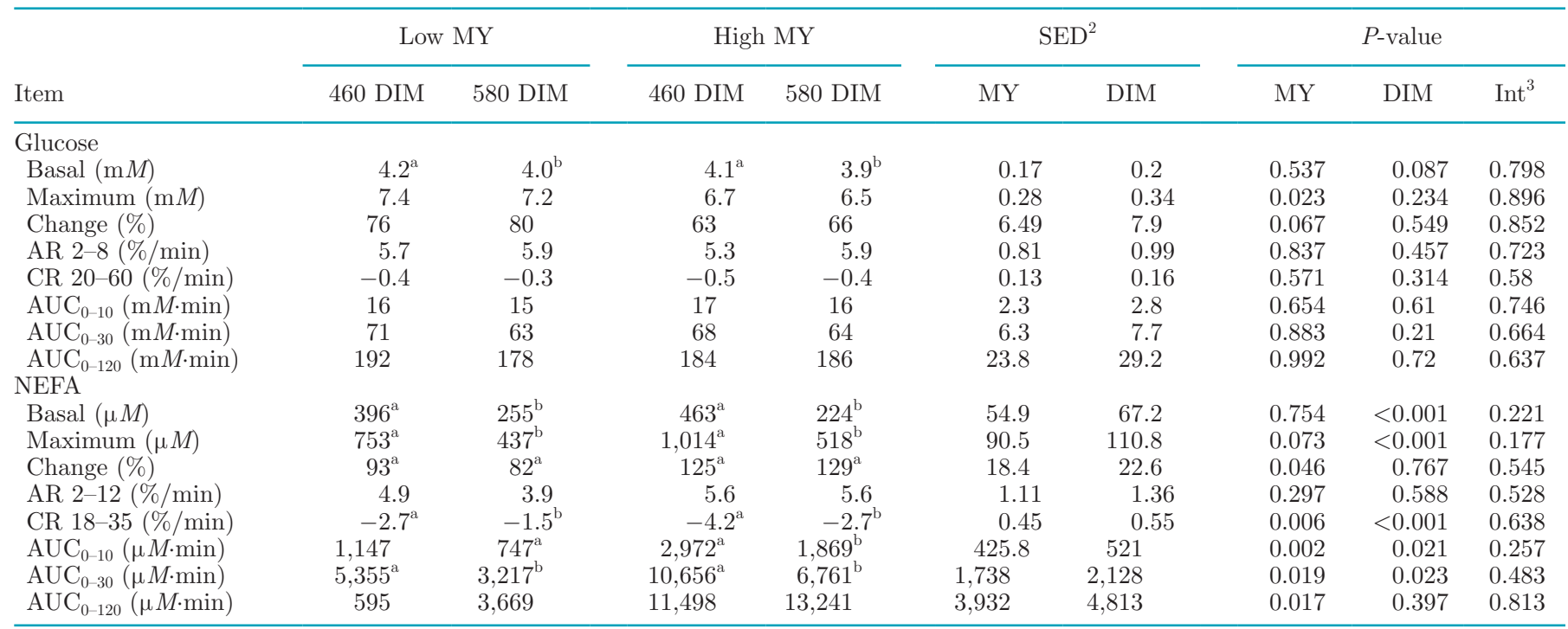

\footnotetext{
${ }^{\mathrm{a}, \mathrm{b}}$ Within a milk yield group, means with different superscripts are statistically different $(P<0.05)$.

${ }^{1}$ Values are means for 6 cows per treatment.

${ }^{2} \mathrm{SED}=$ standard error of the difference.

${ }^{3} \mathrm{Int}=\mathrm{MY} \times \mathrm{DIM}$ interaction.
} 
than $1 \mathrm{~kg}$ of grain, the current data suggest that this was a reflection of the MY of the cows, and not of their dietary intake. The glucogenic and lipolytic sensitivity to catecholamines appear to be related to milk production potential, more so than diet. It is plausible that the sensitivity of cows to catabolic signals is regulated by variations in expression of endocrine receptors and this warrants investigation in cows of greater lactation persistency.

The lipolytic, but not the glucogenic, responsiveness to the high dose of epinephrine was greater in cows of high MY compared with low MY. Thus, our third hypothesis is supported in terms of the NEFA response but not the glucose response. The maximum plasma glucose concentration and the percent change in glucose following the epinephrine infusion were lower in high MY than low MY cows. This may be due to greater plasma glucose uptake by the mammary gland of high MY cows. The maximum plasma NEFA tended to be greater, and the NEFA percent change and NEFA AUC were greater in high MY cows. This is consistent with reports of greater responsiveness to epinephrine in cows with enhanced MY through administration of recombinant somatotropin (Sechen et al., 1990). The plasma NEFA response to epinephrine reflects overall mobilization of adipose tissue. Epinephrine binds to the $\beta$-adrenergic receptors on adipocytes and results in the release of NEFA. This is the net effect of both lipolysis and lipogenesis. To determine the rate of lipolysis, the plasma glycerol response is required. It is generally accepted that lipolysis is primarily under genetic regulation, particularly throughout early lactation, but that lipogenesis is mostly environmentally controlled, including via diet (Kolver et al., 2001; Roche et al., 2009). Our data are in agreement with this and demonstrate that the lipolytic responsiveness is more closely linked to the milk production of cows rather than nutrient intake, even beyond 300 DIM when rates of lipolysis and fat mobilization are low and lipogenesis is favored. These data clearly demonstrate that cows with greater MY have a greater propensity to mobilize energy reserves in response to epinephrine than cows of low MY, even beyond 300 DIM.

Our results explain some of the differences in energy partitioning beyond $300 \mathrm{~d}$ of an extended lactation. Other factors that warrant investigation are genetic
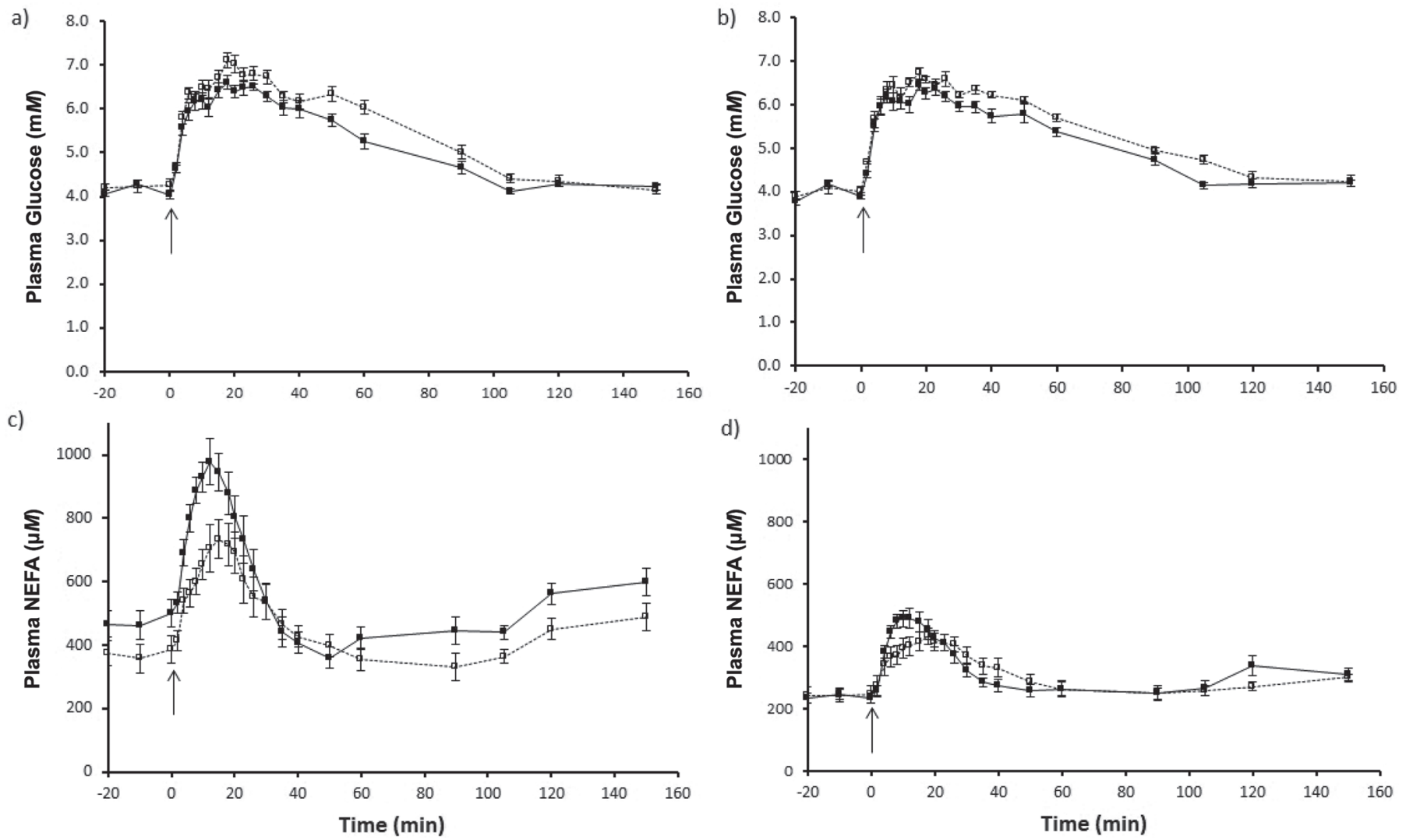

Figure 4. Responses of cows with low milk yield $(\square)$ and high milk yield $(\mathbf{\square})$ to a high-dose epinephrine challenge. Plasma glucose response at (a) 460 and (b) 580 DIM and plasma nonesterified fatty acid (NEFA) response at (c) 460 and (d) 580 DIM. Epinephrine was infused at a dose of $1.6 \mu \mathrm{g} / \mathrm{kg}$ of BW at time 0 min, indicated by arrows. Error bars are SEM. 
factors (genotype, gene expression of receptors associated the regulation of key metabolic pathways including gluconeogenesis, glycolysis, lipolysis, and lipogenesis) and the interaction of these with basal hormone concentrations (e.g., GH). For example, Jaster and Wegner (1981) reported an increase in the number of $\beta$-adrenergic receptors in adipocytes in lactating Holstein-Friesian cows compared with dry cows. More recently this has been confirmed in gene expression studies of $\beta$-adrenergic receptor subtypes (Sumner and McNamara, 2007). As the actions of epinephrine are regulated by its binding to adrenergic receptors, differences in these may account for some of the difference in responsiveness to epinephrine throughout lactation.

In terms of lactation progression and nutrient partitioning, the data from this experiment are consistent with previous reports in different cows (Marett et al., 2011, 2015, 2017, 2018). Throughout lactation, whole animal sensitivity to insulin is altered to maintain milk production, becoming increasingly sensitive to insulin resulting in a re-partitioning of more glucose toward tissue gain rather than milk production. In the current experiment, cow BW increased and basal plasma NEFA decreased, between 460 and 580 DIM, likely at the expense of MY, indicating a lowering of the homeorhetic priority of lactation in all cows. Decreasing circulating concentrations of NEFA are typical of advancing lactation. However, the concentration of NEFA in the plasma at 460 DIM was perhaps greater than expected. This is consistent with previous reports (Marett et al., 2017, 2018). The basal plasma NEFA concentrations in the current experiment are consistent with a second peak in the lactation curve. This has been reported in grazing cows managed for extended lactations, coinciding with a greater availability of pasture in spring following a deficit in winter (Auldist et al., 2007; Kolver et al., 2007; Marett et al., 2011). When measured in early lactation, some hormones and metabolites, and also MY itself, have been associated with extended lactation performance beyond 300 DIM (Kay et al., 2007; Marett et al., 2011). Thus, it is possible that differences in nutrient partitioning are evident from early in lactation. Additional research into the response to metabolic challenges in the early stages of lactation could help to identify cows most suited to extended lactation programs.

The sensitivity and responsiveness to an epinephrine challenge decreases throughout lactation (McNamara, 1988; Marett et al., 2018). The current data are consistent with this and highlight the varied ability of dairy cows with extended lactations to partition nutrients toward milk production at the expense of body tissue stores, even out to 580 DIM. The glucose CR 5-30 during the IVGTT was reduced from 460 to 580 DIM, which is consistent with a reduction in the amount of glucose uptake by the mammary gland as the lactation progressed. Further, responsiveness to the anti-lipolytic actions of insulin was decreased at 580 DIM. The plasma glucose response to the low dose of epinephrine was muted, indicating low sensitivity to epinephrine in terms of hepatic gluconeogenesis and glycogenolysis beyond 300 DIM, and glucose AUC tended to be lower at 580 compared with 460 DIM. The NEFA AUC was lower and the change in plasma NEFA concentration tended to be lower at 580 compared with 460 DIM, indicating decreased lipolytic sensitivity in the very late stages of the extended lactation. These data show that the regulation of nutrient partitioning involves several endocrine pathways. Variations in the sensitivity and responsiveness to catabolic or anabolic signals occur as lactation progresses, not just beyond early lactation, but out to 580 DIM.

The variation in responses to the metabolic challenges was large between cows. This is consistent with the findings from the current series of extended lactation experiments but with different cows (Marett et al., $2015,2017,2018)$. This is partly due to the low number of cows used in the experiments. However, there is an inherent degree of variation in the regulation of nutrient partitioning throughout extended lactations that is likely to be a result of many factors. Dynamic changes in hormone profiles occur throughout both traditional (Bauman, 2000; Kida, 2003) and extended lactations (Sorensen and Knight, 2002; Kay et al., 2009; Marett et al., 2011). Further, with advances in genetic technologies, we are able to investigate the expression of individual hormone receptors within particular tissues. For example, the expression of $\beta$-adrenergic receptors was markedly changed from late pregnancy through to 90 DIM, with the greatest expression occurring at the time of greatest lipolytic responsiveness of adipose tissue (Sumner and McNamara, 2007). Further, the expression of the growth hormone receptor, GHR1A, changes during lactation (Okamura et al., 2009). It is possible that these changes in hormone receptor expression continue to shift throughout the late stages of lactation to affect lactation persistency and individual cow suitability for extended lactations. Maintenance of milk synthesis (persistency) is controlled by systemic and local factors such as hormones, cell number and activity, and feedback inhibition of lactation. When cows are lactating and pregnant at the same time, the energy demands of these processes are contradictory and may lead to a decrease in the secretory activity of mammary cells (Capuco et al., 2003). However, as the cows in this experiment were mated from 450 DIM, the effect of pregnancy on milk production and lactation persistency out to 580 DIM is likely to be negligible. 
Collectively, the results presented here and in Marett et al. $(2015,2017,2018)$ strongly suggest that the difference in whole body and peripheral tissue sensitivity to insulin, and adipose tissue responsiveness to epinephrine, are a function of mainly MY and not energy or feed intake. This raises questions about the effect of genetic regulation of nutrient partitioning in terms of lactation persistency during extended lactations. For example, the expression of growth hormone receptors (i.e., GHR1A), insulin receptors, glucose transporters, along with genes and enzymatic factors involved in lipogenesis and lipolysis, may all affect lactation performance beyond 300 DIM. A review by Abdelsayed et al. (2015) outlined positive genetic correlations between cows with high 305-d MY and those with increased lactation persistency. The literature investigating lactation persistency beyond $300 \mathrm{~d}$ and up to $670 \mathrm{~d}$ are scarce. Further, there were few genetic evaluations or breeding values for persistency traits, with little consistency in the definition of persistency used for analyses. Genome-wide association studies have identified some novel regions of the genome associated with lactation persistency (Pryce et al., 2010; Nayeri et al., 2017). The development of genomic estimated breeding values for performance in an extended lactation could result in breeding high yielding cows with highly persistent lactations.

\section{CONCLUSIONS}

The regulation of nutrient partitioning is coordinated by a very complex interplay of hormones and their receptors that affect the metabolism of glucose and lipids throughout lactation. Importantly, key differences were observed in the responsiveness to the metabolic challenges in cows with high or low MY beyond 460 DIM. Cows that are able to sustain an extended lactation, with high MY to 580 DIM, have a lower whole body and tissue-specific responsiveness to insulin than cows with lower MY. Cows that had higher MY beyond 450 DIM had a greater propensity for adipose tissue mobilization to facilitate their improved MY, irrespective of dietary intake. Further research could explore the potential for using metabolic challenges to test the suitability of cows for extended lactations.

\section{ACKNOWLEDGMENTS}

The authors thank Kristy DiGiacomo, Di Mapleson, Greg Morris, Tony Hookey, Alan McDonald, and the technical and farm staff (Department of Economic Development, Jobs, Transport and Resources, Ellinbank, Australia) for their assistance with sampling and cow husbandry. This work was financially supported by the Geoffrey Gardiner Dairy Foundation (Melbourne, Australia), the University of Melbourne (Melbourne, Australia), and the Department of Economic Development, Jobs, Transport and Resources, Victoria, Australia.

\section{REFERENCES}

Abdelsayed, M., P. C. Thomson, and H. W. Raadsma. 2015. A review of the genetic and non-genetic factors affecting extended lactation in pasture-based dairy systems. Anim. Prod. Sci. 55:949-966. https://doi.org/10.1071/AN13300.

Auldist, M. J., G. N. O'Brien, D. J. Cole, K. L. Macmillan, and C. Grainger. 2007. Effects of varying lactation length on milk production capacity of cows in pasture-based dairying systems. J. Dairy Sci. 90:3234-3241. https://doi.org/10.3168/jds.2006-683.

Bauman, D. E. 2000. Regulation of nutrient partitioning during lactation: Homeostasis and homeorhesis revisited. Pages 311-328 in Ruminant Physiology: Digestion, Metabolism, Growth and Reproduction. P. B. Cronje, ed. CAB International, New York, NY.

Blum, J. W., P. Kunz, H. Leuenberger, K. Gautschi, and M. Keller. 1983. Thyroid hormones, blood plasma metabolites and haematological parameters in relation to milk yield in dairy cows. Anim. Sci. 36:93-104. https://doi.org/10.1017/S0003356100039982.

Brehm, A., K. Thomaseth, E. Bernroider, P. Nowotny, W. Waldhausl, G. Pacini, and M. Roden. 2006. The role of endocrine counterregulation for estimating insulin sensitivity from intravenous glucose tolerance tests. J. Clin. Endocrinol. Metab. 91:2272-2278. https:/ /doi.org/10.1210/jc.2006-0019.

Buckley, B. A.. J. H. Herbein, and J. W. Young. 1982. Glucose kinetics in lactating and nonlactating dairy goats. J. Dairy Sci. 65:371-384. https://doi.org/10.3168/jds.S0022-0302(82)82201-7.

Capuco, A. V., S. E. Ellis, S. A. Hale, E. Long, R. A. Erdman, X. Zhao, and M. J. Paape. 2003. Lactation persistency: Insights from mammary cell proliferation studies. J. Anim. Sci. 81:18-31. https: //doi.org/10.2527/2003.81suppl_318x.

Chagas, L. M., M. C. Lucy, P. J. Back, D. Blache, J. M. Lee, P. J Gore, A. J. Sheahan, and J. R. Roche. 2009. Insulin resistance in divergent strains of Holstein-Friesian dairy cows offered fresh pasture and increasing amounts of concentrate in early lactation. J. Dairy Sci. 92:216-222. https://doi.org/10.3168/jds.2008-1329.

Collier, R. J., J. P. McNamara, C. R. Wallace, and M. H. Dehoff. 1984 A review of endocrine regulation of metabolism during lactation. J. Anim. Sci. 59:498-510.

Cronje, P. B. 2000. Nutrient-gene interactions: Future potential applications. Pages 409-422 in Ruminant Physiology: Digestion, Metabolism, Growth and Reproduction. P. B. Cronje, ed. CAB International, New York, NY.

Delany, K. K., K. L. Macmillan, C. Grainger, P. C. Thomson, D. Blache, K. R. Nicholas, and M. J. Auldist. 2010. Blood plasma concentrations of metabolic hormones and glucose during extended lactation in grazing cows or cows fed a total mixed ration. J. Dairy Sci. 93:5913-5920. https://doi.org/10.3168/jds.2010-3609.

Denbow, C. J., K. S. Perera, F. C. Gwazdauskas, R. M. Akers, R. E. Pearson, and M. L. McGilliard. 1986. Effect of season and stage of lactation on plasma insulin and glucose following glucose injection in Holstein cattle. J. Dairy Sci. 69:211-216.

Dunshea, F. R., A. W. Bell, and T. E. Trigg. 1990. Non-esterified fatty acid and glycerol kinetics and fatty acid re-esterification in goats during early lactation. Br. J. Nutr. 64:133-145. https://doi.org/10 .1079/BJN19900016.

Ferrannini, E., S. Camastra, S. W. Coppack, D. Fliser, A. Golay, and A. Mitrakou. 1997. Insulin action and non-esterified fatty acids. Proc Nutr. Soc. 56:753-761. https://doi.org/10.1079/PNS19970076.

Grainger, C., M. J. Auldist, G. O'Brien, K. L. Macmillan, and C. Culley. 2009. Effect of type of diet and energy intake on milk production of Holstein-Friesian cows with extended lactations. J. Dairy Sci. 92:1479-1492. https://doi.org/10.3168/jds.2008-1530. 
Jaster, E. H., and T. N. Wegner. 1981. Beta-adrenergic receptor involvement in lipolysis of dairy cattle subcutaneous adipose tissue during dry and lactating state. J. Dairy Sci. 64:1655-1663.

Johnson, M. M., and J. P. Peters. 1993. Technical note: An improved method to quantify nonesterified fatty acids in bovine plasma. J. Anim. Sci. 71:753-756. https://doi.org/10.2527/1993.713753x.

Kaneko, J. J. 1997. Carbohydrate metabolism and its diseases. Pages 45-81 in Clinical Biochemistry of Domestic Animals. J. J. Kaneko, ed. Academic Press, San Diego, CA.

Kay, J. K., P. W. Aspin, C. V. C. Phyn, J. F. Roche, and E. S. Kolver. 2007. Production and physiological indicators to select cows suitable for extended lactation. Vol. 67. Pages 315-319 in Proc. New Zealand Soc. Anim. Prod.

Kay, J. K., C. V. C. Phyn, J. F. Roche, and E. S. Kolver. 2009. Extending lactation in pasture-based dairy cows II: Effect of genetic strain and diet on plasma hormone and metabolite concentrations. J. Dairy Sci. 92:3704-3713. https://doi.org/10.3168/jds.2008-1976.

Kida, K. 2003. Relationships of metabolic profiles to milk production and feeding in dairy cows. J. Vet. Med. Sci. 65:671-677.

Kolver, E. S., J. R. Roche, M. de Veth, and T. R. Mackle. 2001. Lipolytic response of New Zealand and overseas Holstein-Friesian dairy cows challenged with epinephrine. Vol. 61. Pages 48-51 in Proc. New Zealand Soc. Anim. Prod., Christchurch.

Kolver, E. S., J. R. Roche, C. R. Burke, J. K. Kay, and P. W. Aspin. 2007. Extending lactation in pasture-based dairy cows: I. Genotype and diet effect on milk production. J. Dairy Sci. 90:5518 5530. https://doi.org/10.3168/jds.2007-0324.

Marett, L. C., M. J. Auldist, C. Grainger, W. J. Wales, D. Blache, K. L. Macmillan, and B. J. Leury. 2011. Temporal changes in plasma concentrations of hormones and metabolites in pasture-fed dairy cows during extended lactation. J. Dairy Sci. 94:5017-5026. https: //doi.org/10.3168/jds.2011-4272.

Marett, L. C., M. J. Auldist, P. J. Moate, W. J. Wales, K. L. Macmillan, F. R. Dunshea, and B. J. Leury. 2015. Response of plasma glucose, insulin, and nonesterified fatty acids to intravenous glucose tolerance tests in dairy cows during a 670-day lactation. J. Dairy Sci. 98:179-189. https://doi.org/10.3168/jds.2014-8205.

Marett, L. C., M. J. Auldist, W. J. Wales, K. L. Macmillan, K. DiGiacomo, and B. J. Leury. 2014. Evaluation of growth hormone response to insulin-induced hypoglycaemia in dairy cattle during a 670-day lactation. Anim. Prod. Sci. 54:1323-1327. https://doi .org/10.1071/AN14224.

Marett, L. C., M. J. Auldist, W. J. Wales, K. L. Macmillan, F. R Dunshea, and B. J. Leury. 2017. Responses of plasma glucose and nonesterified fatty acids to intravenous insulin tolerance tests in dairy cows during a 670-day lactation. J. Dairy Sci. 100:32723281. https://doi.org/10.3168/jds.2016-11985.

Marett, L. C., M. J. Auldist, W. J. Wales, K. L. Macmillan, F. R. Dunshea, and B. J. Leury. 2018. Plasma glucose and nonesterified fatty acids response to epinephrine challenges in dairy cows during a 670-d lactation. J. Dairy Sci. 101:3501-3513. https://doi.org/10 $.3168 /$ jds.2017-13614.

McGuire, M. A., J. M. Griinari, D. A. Dwyer, and D. E. Bauman. 1995. Role of insulin in the regulation of mammary synthesis of fat and protein. J. Dairy Sci. 78:816-824. https://doi.org/10.3168/jds .S0022-0302(95)76693-0.

McNamara, J. P. 1988. Regulation of bovine adipose tissue metabolism during lactation. 4. Dose-responsiveness to epinephrine as al- tered by stage of lactation. J. Dairy Sci. 71:643-649. https://doi .org/10.3168/jds.S0022-0302(88)79602-2.

Nayeri, S., M. Sargolzaei, M. K. Abo-Ismail, S. Miller, F. Schenkel, S. S. Moore, and P. Stothard. 2017. Genome-wide association study for lactation persistency, female fertility, longevity, and lifetime profit index traits in Holstein dairy cattle. J. Dairy Sci. 100:12461258. https://doi.org/10.3168/jds.2016-11770.

Okamura, C. S., J. F. Bader, D. H. Keisler, and M. C. Lucy. 2009. Short communication: Growth hormone receptor expression in two dairy breeds during the periparturient period. J. Dairy Sci. 92:2706-2710. https://doi.org/10.3168/jds.2008-1775.

Pryce, J. E., M. Haile-Mariam, K. Verbyla, P. J. Bowman, M. E. Goddard, and B. J. Hayes. 2010. Genetic markers for lactation persistency in primiparous Australian dairy cows. J. Dairy Sci. 93:2202-2214. https://doi.org/10.3168/jds.2009-2666.

Roche, J. R., N. C. Friggens, J. K. Kay, M. W. Fisher, K. J. Stafford, and D. P. Berry. 2009. Invited review: Body condition score and its association with dairy cow productivity, health, and welfare. J. Dairy Sci. 92:5769-5801. https://doi.org/10.3168/jds.2009-2431.

Sechen, S. J., F. R. Dunshea, and D. E. Bauman. 1990. Somatotropin in lactating cows: Effect on response to epinephrine and insulin. Am. J. Physiol. 258:E582-E588. https://doi.org/10.1152/ajpendo .1990.258.4.E582.

Sechen, S. J., S. N. McCutcheon, and D. E. Bauman. 1989. Response to metabolic challenges in early lactation dairy cows during treatment with bovine somatotropin. Domest. Anim. Endocrinol. 6:141-154. https://doi.org/10.1016/0739-7240(89)90043-X.

Sorensen, A., and C. H. Knight. 2002. Endocrine profiles of cows undergoing extended lactation in relation to the control of lactation persistency. Domest. Anim. Endocrinol. 23:111-123. https://doi .org/10.1016/S0739-7240(02)00150-9.

Sorensen, A., D. D. Muir, and C. H. Knight. 2008. Extended lactation in dairy cows: Effects of milking frequency, calving season and nutrition on lactation persistency and milk quality. J. Dairy Res. 75:90-97. https://doi.org/10.1017/S0022029907002944.

Stanton, T. L., L. R. Jones, R. W. Everett, and S. D. Kachman. 1992. Estimating milk, fat, and protein lactation curves with a test day model. J. Dairy Sci. 75:1691-1700. https://doi.org/10.3168/jds .S0022-0302(92)77926-0.

Sumner, J. M., and J. P. McNamara. 2007. Expression of lipolytic genes in the adipose tissue of pregnant and lactating Holstein dairy cattle. J. Dairy Sci. 90:5237-5246. https://doi.org/10.3168/ jds.2007-0307.

Tekerli, M., Z. Akinci, I. Dogan, and A. Akcan. 2000. Factors affecting the shape of lactation curves of Holstein cows from the Balikesir province of Turkey. J. Dairy Sci. 83:1381-1386. https://doi.org/10 .3168/jds.S0022-0302(00)75006-5.

Tilton, S. L., P. S. Miller, A. J. Lewis, D. E. Reese, and P. M. Ermer. 1999. Addition of fat to the diets of lactating cows: I effects on milk production and composition and carcass composition of the litter at weaning. J. Anim. Sci. 77:2491-2500.

Tindal, J. S., G. S. Knaggs, I. C. Hart, and L. A. Blake. 1978. Release of growth hormone in lactating and non-lactating goats in relation to behaviour, stages of sleep, electroencephalograms, environmental stimuli and levels of prolactin, insulin, glucose and free fatty acids in the circulation. J. Endocrinol. 76:333-346. https://doi.org/ $10.1677 /$ joe. 0.0760333 . 